\title{
Discussion on the Education Mode of Innovation and Entrepreneurship in Chinese Colleges and Universities
}

\author{
Wei Cuijuan \\ Education College, Shaanxi Normal University, Xi’an, Shaanxi, China,710062
}

Keywords: innovation and entrepreneurship education; education mode; colleges and universities

\begin{abstract}
Under the background of "national entrepreneurship and innovation", Chinese universities education has become the new development strategy target, which plays an important role in China's economic transformation. As the key communicator of education innovation and entrepreneurship, Chinese colleges and universities have a mission to build the education system and promote the high-quality entrepreneurship of college students. Based on the typical Chinese innovation and entrepreneurship education mode, this paper proposes suggestions for improving the existing education model. This paper is hopefully to provide a new idea for China's innovation and entrepreneurship education, and improve the success rate of college students' entrepreneurship on the basis of perfecting the education system of innovation and entrepreneurship in China.
\end{abstract}

\section{Introduction}

The core of education for innovation and entrepreneurship in Chinese universities is that the audience group promotes the students' individual development and comprehensive development when accepting the long-term education of the university. Then, according to the basic characteristics of students, develop a set of personalized comprehensive development suitable for their development path. Generally, there are four aspects. First, pay attention to the cultivation of students' innovative consciousness and cultivate their ability to aply innovative consciousness to work and life. Second, encourage students to develop personalized thinking, and do not imprison their own thoughts. Thirdly, when cultivating the individualized thinking, we should pay attention to the avoidance of the sprout of individualism. Fourthly, different forms of students' different characteristics are cultivated to cultivate their innovative spirit.

\section{Typical Education Model of Innovation and Entrepreneurship in Chinese Colleges and Universities}

\subsection{Main education mode}

The education model of Chinese universities advocates the theme of people as education. This mode is the main way to cultivate students' creativity and subjective initiative, and eventually develop students into a comprehensive and comprehensive development. It mainly consists of three aspects: education subject, subject of teaching and teaching subject. Education mainly focuses on the initiative of education subject and the cultivation mode of independence. The subject of education is the main body of teenagers who accept education, and the teaching subjects are schools and teachers. In general, education mode is the main body of education, and it is regarded as the highest value of education. The personality and subjectivity of education people will be an important way to cultivate their values. To sum up, the education mode is a education method combining the subjectivity, entrepreneurial awareness, entrepreneurial ability and entrepreneurial practice of college students. This education method is based on college students, and it is believed that the cultivation of students' subjectivity will enhance their innovation ability and enhance their entrepreneurial ability. 


\subsection{Personalized education mode}

Personalized education has already become the top priority of education innovation in China, and China's education training mode for university innovation and entrepreneurship also has the mode of personalized education as the main training mode. The personalized education mode has more respect for students' different personalities, and carries out different forms of cultivation methods and training plans according to their diversity. The personalized education mode fully develops students' personality characteristics and makes different teaching contents, methods and mechanism according to their characteristics. The diversity of students' personalities is formed by their family background, education background and personality characteristics, etc. The education mode will provide different and targeted training programs for their different characteristics and physical and mental development rules. This training program will lay the foundation for promoting students' subjective initiative and individual characteristics. In the end, the comprehensive development of its moral and physical beauty and the cultivation of better social talents.

\subsection{Comprehensively develop education mode}

The comprehensive development of education was proposed in the early 21st century, and was widely recognized by the educational circles. The education mode mainly advocates the following two points: First, combine mental and physical strength to promote the overall development of students. Second, give full play to individual talents and promote the coordinated development of individual talents and quality. This education mode requires that students should be trained to develop education in a comprehensive way while respecting their own development. Comprehensively develop education develops self-determination and problem-solving ability through social practice, and promote the all-round development of college students. Compared with the personalized education, the problem of comprehensive development of education mode is more profound, which is more helpful for students' future needs.

\section{Establish the Education Mode of Innovation and Entrepreneurship}

\subsection{Curriculum setting of innovation and entrepreneurship education}

Innovation and entrepreneurship courses should not only consider the characteristics of students, but also combine specialized courses and practical courses effectively. This article is mainly introduced from the following two points: First, the curriculum must focus on innovative features. This is mainly because the innovation and entrepreneurship activities need to be innovated to cultivate students' innovative features, and teachers need to integrate the key points in teaching and innovation and entrepreneurship activities. Innovation and entrepreneurship courses are very strict in the requirements of entrepreneurial activities. A good entrepreneurial activity will open up a window for college students to start a business and make them genuinely interested in innovative entrepreneurship courses. In the course, we can set some interpersonal communication and language expression courses. This course lays the foundation for the later innovation and entrepreneurship practice activities, and provides students with the preparation for the real practical courses. Second, the course construction must pay attention to entrepreneur characteristics. Entrepreneurs in innovation and entrepreneurship are the main body. In this process, entrepreneurs need to have strong innovation and management ability. So, innovation and entrepreneurship courses must cultivate students' innovation ability and management ability as the main training purpose. While improving students' innovative consciousness, they should pay attention to improving their management ability.

\subsection{Teaching of innovation and entrepreneurship training}

Education is the basic platform for Chinese college students to realize their business. Chinese colleges and universities combine innovation and theory to promote innovation and entrepreneurship action through teaching, research, practice and incubation. Chinese universities mainly teach two kinds of innovation and entrepreneurship training programs. First, campus 
innovation and entrepreneurship incubator program. Chinese colleges and universities often support college students to start their own businesses by holding innovation and entrepreneurship education practice. Colleges and universities also cooperate with science and technology parks to provide practical training opportunities for college students. The science park will be staffed with special staff to help students, and provide start-up capital support for students with good projects. Second, the innovation and entrepreneurship base of colleges and universities and the entrepreneurial projects launched by the government. The innovation and entrepreneurship of college students need the strong support from the government and the correct guidance of colleges and universities. Colleges and universities should strongly support students to carry out entrepreneurial projects, and actively work with local governments to establish entrepreneurial projects. This can increase the rate at which college students can incubate their own entrepreneurial projects.

\subsection{Entrepreneurial practice teaching}

Practical teaching is an important way to improve the results of innovation and entrepreneurship education, and it can also detect the possibility of the project's success. Colleges and universities should renovate the current practice teaching system and create a new kind of practice teaching base. It can be guaranteed that any student who wants to put into practice can start their own projects at the practical teaching base. In addition, colleges and universities should strengthen inter-school cooperation and open up off-campus training platforms. In order to promote the reform of college students' entrepreneurship training. Chinese colleges and universities should establish high-quality innovation and entrepreneurship education team by promoting innovation in entrepreneurship practice. It also improves the students' practice level by comparing the content of the practical training program and the subject. Colleges and universities should use practical projects to enhance their innovation and entrepreneurship education level, and provide a steady stream of new entrepreneurial talents for the country. Chinese universities should compete in various entrepreneurship competitions such as "challenge cup" and "startup nova" to promote entrepreneurship.

\section{Conclusion}

The current innovation and entrepreneurship education in Chinese universities must break the shackles of existing models. In the course of teaching, lectures or lectures, the current traditional teaching mode can be innovated by various practical modes and teaching methods. This paper introduces the education mode of innovation and entrepreneurship in China, and then renovates the traditional teaching by constructing the education mode of innovation and entrepreneurship. Through the combination of teaching and practice, we can improve the success rate of innovation and entrepreneurship. We can promote the long-term development of innovation and entrepreneurship education through the construction of innovation and entrepreneurship education mode.

\section{Acknowledgement}

Project of Science \& Technology Bureau, Chang'an District, Xi'an: Research on Construction of Chuang Yi Incubation Base of Xi'an FANYI University NO. CC1702

\section{References}

[1] Hurd ppD. Scientific Literacy: New Minds for Changing World. Science Education (2008), p. 407-416

[2] Beyer, C.H, Gilinore, G.M., Fisher, A.T. Inside the Undergraduate Experience: TheUniversity of Washington's Study of Undergraduate Learning. Bolton: Anker, Publishing Company (2007), p. 32-35 
[3] Semra Guven. World Conference on Edueational Seiences New primary edueationcourse programmes and entrepreneurship. Proeedia Social and Behavioral Seiences. (2009), p. 265-270

[4] Mclagan. Great ideas revisited. Training and Development (1996), p. 60-65

[5] Einar A, Rasm Jssen Roger Sorheim. Aetiorr-based. eneurship education. TenTeehnovation (2006), p. 185

[6] Helge Berglann; EsPenR. Moen, KnutRoed, etal. Entre PreneurshiP: Originsandreturns. LabourEeonomies (2011), p. 180-193

[7] Roediger Voss. Thorsten Gruberjsabelle Szmigin."Service quality in higher education: Therole of student expectations". Journal of Business- Research (2007), p. 949-959 